\title{
HERMENEUTIKA FEMINIS: KRITIK ATAS KESETARAAN FATIMA MERNISSI
}

\author{
Lub Liyna Nabilata \\ Mahasiswa Pascasarjana UIN Sunan Kalijaga Yogyakarta \\ Email: Lubliynanabilata1@gmail.com
}

\begin{abstract}
Cultural optics will always appear in every debate about feminism, as well as certain interpretive tendencies (read: pre-text) also involved (enveloped) and even come into play in them. Therefore, the emergence of different views even somewhat "biased" is considered normal. People in discussing feminism will not be able to position themselves really objectively without pretension, but can only maintain a distance from prejudices or "biases" that can unwittingly emerge. In Muslim feminist thought, they are still trapped in a crisis of interpretation and counter interpretation. This crisis arises because the methods or strategies used by opponents and supporters of gender equality in building and legitimizing each of their views are basically the same, namely by explaining certain parts of the text of the Qur'an or hadith that are appropriate and support their interests and views. The parts of the text are then considered as asl the most correct and original principles, which in turn tend to be interpreted unilaterally in accordance with their ideological interests and positions and at the same time eliminate unwanted meanings because they are contrary to their ideological interests. This eclectic reading model is caused by the inability to challenge the existing paradigm of reading the text, which does not consider the historical context, dialogical and communicative aspects of the text with its context, and its descriptive dimensions. In this article intending to criticize the interpretation of Fatima Mernissi, Mernissi seems to still have a subjective bias in assessing some of the problems of feminist interpretation regarding equality of men and women, and not occupying the core of the problem in the actual portion. As a result, this argument shows that Mernissi is still narrow in using her feminist approach, because the core feminist approach is actually sensitive to injustice and avoiding "bias" that can occur not only in gender issues, but can also occur in other areas related to sara (read: skin color, tribe, caste and others).
\end{abstract}

\begin{abstract}
Abstrak
Optik kultural akan selalu muncul dalam setiap perdebatan tentang feminisme, begitu pula kecenderungan interpretasi tertentu (baca: pra teks) ikut juga terlibat (enveloped) dan bahkan ikut bermain di dalamnya. Oleh sebab itu, munculnya pandangan-pandangan yang berbeda bahkan agak "bias" sudah dianggap lumrah. Seseorang dalam membicarakan feminisme tidak akan dapat memposisikan diri dengan benar-benar obyektif tanpa pretensi, melainkan hanya dapat menjaga jarak terhadap prasangka (Prejudices) atau "bias" yang tanpa disadari dapat saja muncul. Dalam pemikiran feminis muslim masih terjebak dalam krisis penafsiran
\end{abstract}


dan konter penafsiran. Krisis ini muncul karena cara atau strategi yang digunakan oleh penentang dan pendukung kesetaraan gender dalam membangun dan melegitimasi masing-masing pandangannya pada dasarnya sama, yakni dengan menjelaskan bagian-bagian tertentu dari teks al-Qur'an atau hadis yang sesuai dan mendukung kepentingan dan pandangan mereka. Bagian-bagian dari teks tersebut kemudian dianggap sebagai asl yang paling benar dan orisinal, yang pada gilirannya cenderung diinterpretasikan secara sepihak sesuai dengan kepentingan dan posisi ideologis mereka dan sekaligus mengeliminasi makna yang tidak diinginkan karena bertentangan dengan kepentingan ideologisnya. Model pembacaan eklektik ini disebabkan karena ketidakmampuan untuk menantang paradigma pembacaan teks yang ada, yang tidak mempertimbangkan konteks historis, aspek dialogis dan komunikatif teks dengan konteksnya, serta dimensi deskriptifnya. Dalam artikel ini bermaksud untuk mengkritisi penafsiran Fatima Mernissi, Mernissi terlihat masih memiliki bias subyektif dalam menilai beberapa problematika tafsir feminis perihal kesetaraan laki-laki dan perempuan, dan tidak mendudukan inti persoalannya dalam porsi yang sebenarnya. Walhasil dengan argumentasi tersebut, menunjukkan bahwa Mernissi masih sempit dalam menggunakan pendekatan feminisnya, karena inti pendekatan feminis sebenarnya adalah peka terhadap ketidakadilan dan menghindari "bias" yang dapat saja terjadi tidak hanya dalam isu gender, melainkan dapat juga terjadi di dalam wilayah lain berkaitan dengan sara (baca: warna kulit, suku, kasta dan lain-lain).

Keywords: hermeneutics, feminists, Fatima Mernissi, Equality

\section{PENDAHULUAN}

Tafsir al-Qur'an dan gender adalah dua entitas yang masing-masing bisa berdiri sendiri tanpa saling menyapa. Masing-masing entitas tumbuh dan berkembang dalam dunianya sendiri, yang satu dipandang menghuni dunia sakral dan yang lainnya di dunia profan. Tapi, ketika dikaitkan dengan ide keadilan yang merupakan kebutuhan mutlak kehidupan manusia, maka tersingkap bahwa dalam tafsir alquran terkandung hal-hal yang merugikan perempuan, melumpuh peranperan sosial perempuan dan menjauhkan perempuan dari tujuan Islam sebagai rahmah bagi seluruh umat.

Keadilan adalah prinsip kehidupan yang harus dipenuhi, karenanya segala bentuk ketidakadilan harus dikritisi. Dalam masyarakat Islam masih kuat anggapan bahwa kedudukan perempuan lebih rendah dari laki-laki. Kemanusiaan perempuan dipandang tidak utuh dan eksistensi perempuan hanya melengkapi dan melayani laki-laki. Anggapan ini mengakibatkan perempuan mengalami berbagai 
bentuk diskriminasi. Inilah yang disebut dengan ketidakadilan gender. Ketidakadilan gender dalam masyarakat Islam disebabkan oleh bias gender dalam penafsiran alquran. ${ }^{1}$

Keberadaan tafsir sejauh ini yang beredar di kalangan umat Islam mayoritas adalah tafsir yang lahir dari sentuhan pemikiran para ulama laki-laki, sehingga kesalahan-kesalahan yang umum terjadi adalah perihal pemahaman dan pandangan terhadap pembacaan teks yang terkadang hanya didasarkan atas subjektifitas atau sudut pandang pribadi mereka. Akibatnya entah secara sadar atau tidak, penafsiran mereka mengandung aspek-aspek yang bias gender, yang berimplikasi terhadap ketimpangan cara pandang dan keadilan terhadap kaum perempuan.

Menurut sebagian perempuan, pembacaan teks keagamaan (al-Quran dan hadis) selama ini cenderung dianggap kurang tepat dengan dinamika situasi, kondisi, dan masa yang ada. Sehingga hal tersebut memicu terhadap lahirnya pandangan negatif terhadap teks keagamaan umat Islam. Teks-teks yang dilahirkan atas petunjuk Allah ini dianggap mengandung ketidakadilan sekaligus ketimpangan terhadap hamba-hamba ciptaanNya. Padahal kesalahan yang terjadi tidak disebabkan oleh keberadaan teks tersebut, melainkan terletak pada pembacaan yang tidak tepat terhadap tafsir.

Tafsir alquran yang merupakan salah satu sumber legitimasi ajaran agama memberi pandangan yang tidak akomodatif terhadap nilai-nilai kemanusiaan perempuan. Perempuan tidak diakui sebagai manusia utuh, tidak berhak mempresentasikan diri, dilarang menjadi pemimpin, dipojokkan sebagai makhluk domestic, harus menjadi istri yang taat suami dan harus rela bila suami berpoligami sampai dengan empat istri. Atas nama agama, perempuan diposisikan sebagai objek hukum, khususnya hulum yang berkaitan dengan hukum keluarga

\footnotetext{
${ }^{1}$ Musdah Mulia, Indahnya Menyuarakan Kesetaraan dan Keadilan Gender, (Yogyakarta: Naufan, 2014), hal. 87
} 
seperti hukum perkawinan dan pewarisan. ${ }^{2}$ Dalam kitab-kitab tafsir klasik termuat pandangan bahwa laki-laki adalah jenis kelamin utama, sedang perempuan sebagai jenis kelamin kedua. Bias gender dalam penafsiran alquran seperti ini masih dijadikan referensi dalam melegalkan pola hidup patriarki. ${ }^{3}$

Realitas inilah yang kemudian mendorong sebagian intelektual Islam untuk menafsirkan kembali teks-teks religious untuk menderivasikan nilai-nilai moral yang mengafirmasi kesetaraan manusia, yang bisa dijadikan sebagai basis teologis praksis dalam membebaskan perempuan dari berbagai subordinasi tersebut. Salah satu tokoh yang intens perhatiannya dalam persoalan ini adalah Fatima Mernissi yang dalam berbagai karyanya berupaya untuk mengkritik pemikiran dan interpretasi yang bias gender dan berupaya melakukan rekonstruksi pemahaman keagamaan yang mendukung penghargaan dan penghormatan yang setara terhadap perempuan.

Di sisi lain, interpretasinya juga menjadi kritik terhadap feminisme ${ }^{4}$ liberal yang menurutnya tidak sepenuhnya kompatibel dengan Islam. Tawarannya ini secara politis bisa dimaknai sebagai kritiknya terhadap kolonialisme dimana feminisme liberal merupakan anak kandungnya, dan juga secara religius merupakan bentuk keyakinannya bahwa Islam juga memiliki nilai-nilai dan ajaran yang mengafirmasi kesetaran gender yang ada tidak hanya secara tekstual dalam al-Qur'an dan hadis, tapi secara praktis juga dicontohkan oleh Nabi Muhammad.

Dalam tulisan ini bermaksud untuk mengkritisi penafsiran Fatima Mernissi, Mernissi terlihat masih memiliki bias subyektif dalam menilai beberapa problematika tafsir feminis perihal kesetaraan laki-laki dan perempuan, dan tidak

\footnotetext{
${ }^{2}$ Musdah Mulia, Muslimah Sejati Menempuh Jalan Islami, Meraih Ridho Ilahi, (Bandung: Marja, 2011), h. 98

${ }^{3}$ Nasaruddin Umar, Argumen Kesetaraan Gender: Perspektif Alquran, (Jakarta: Paramadina, 1999)

4 Dalam wacana feminism, perempuan digambarkan sebagai manusia yang mengalami diskriminasi dan ketidakadilan, sehingga muncul perjuangan untuk mencapai kesetaraan dan keadilan gender. Perjuangan tersebut diawali oleh pergerakan feminism Barat yang muncul di awal tahun 1970-an dan di tahun 1980-an teori-teori feminism menyerbu dunia universitas. Pergerakan dan pemikiran feminisme kemudian disambut secara global dan dikaji secara ilmiah, termasuk dalam konteks Islam menyimak berbagai literature tentang kesetaraan dan keadilan gender dalam Islam.
} 
mendudukan inti persoalannya dalam porsi yang sebenarnya. Dengan argumentasi tersebut, menunjukkan bahwa Mernissi masih sempit dalam menggunakan pendekatan feminisnya, karena inti pendekatan feminis sebenarnya adalah peka terhadap ketidakadilan dan menghindari "bias" yang dapat saja terjadi tidak hanya dalam isu gender, melainkan dapat juga terjadi di dalam wilayah lain berkaitan dengan sara (baca: warna kulit, suku, kasta dan lain-lain).

\section{Mengenal Fatima Mernissi}

Fatima Mernissi, dilahirkan di kota Fez, Maroko Utara pada tahun 1940. Ia berasal dari keluarga kelas menengah di sebuah harem, dalam lingkungan harem tersebut, kegelisahan intelektualnya bermula. Bersama sepupunya (Chama), Mernissi kecil selalu bertanya tentang harem, atau makna keterkukungan dalam harem. Sebagian anggota keluarganya (yang perempuan) menganggap harem sebagai hal yang baik. Sebagian lagi, termasuk ibunya yang sering melakukan protes terhadap pemisahan ruangan antara keluarganya dan keluarga pamannya, merupakan kelompok anti harem. Secara langsung maupun tidak, tindakan ibunya tersebut menanamkan kepadanya gagasan pembebasan dan pemberontakan perempuan. $^{5}$

Pendapat Lala Yasmina (neneknya), yang menyatakan bahwa batasanbatasan harem lebih dari sekedar batas-batas dinding yang secara fisik membatasi ruang gerak perempuan, juga merupakan bibit kesadaran Mernissi atas keterkukungan perempuan. ${ }^{6}$ Di luar lingkungan keluarganya, Mernissi mendapatkan pendidikan taingkat pertama di sekolah tradisional yang didirikan oleh golongan nasionalis, yang mengajarkan al-Qur'an dengan sistem pelajaran yang keras. Hal ini berbeda dengan pelajaran yang diterima dari neneknya, di mana al-Qur'an telah membukakan pintu baginya menuju sebuah agama yang puitis, yang dapat membawa ke dalam mimpi bukannya menjadi pelemah semangat belaka. ${ }^{7}$

\footnotetext{
${ }^{5}$ Fatima Mernissi, Women and Islam: An Historical and Theological Inquiry, alih bahasa oleh Yaziar, (Bandung: Pustaka, 1991), h. 6

${ }^{6}$ Fatima Mernissi,..........h. 69

${ }^{7}$ Fatima Mernissi,........... 79
} 
Perkenalannya dengan hadis yang terjadi di sekolah menengah, justru mengguncang perasaannya. Kitab al-Bukhari yang diajarkan sang guru, di dalamnya menyebutkan bahwa "Anjing, keledai dan wanita, akan membatalkan shalat seseorang apabila melintas di hadapan mereka, menyela antara orang yang shalat dengan qiblat". Hal itu membuatnya hampir tak pernah mengulangi hadis tersebut, dengan harapan kebisuan bahwa hadis ini akan terhapus dari ingatannya. Ia tak habis pikir, bagaimana mungkin Rasulullah mengatakan hadis yang bisa melukai perasaan gadis cilik seperti dirinya. Menginjak dewasa, Mernissi merasakan kebutuhan yang mendesak untuk mengumpulkan informasi mengenai hadis-hadis

yang menurutnya menyudutkan perempuan (misoginis), lalu mencari nash-nash tersebut untuk dapat memahaminya dengan baik. Perjalanan intelektual berikutnya dia dapatkan di Universitas Mohammed V di Rabbat, Mernissi mengambil program ilmu politik yang diselesaikannya pada tahun 1965. kemudian ia melanjutkan ke Paris, dan menyelesaikan program doktornya dalam bidang sosiologi di Universitas Brandeis pada tahun 1973, dimana Beyond The Veil merupakan disertasinya. Mernissi sempat bekerja sebagai wartawan (Amal Rasaam, dalam John L. Espsito (ed)., 1995: 93).

Sekembalinya ke Maroko, ia mengajar pada Departemen Sosiologi di Universitas Mohammed V, sekaligus menjadi dosen The Institute of Scientific Research, pada Universitas yang sama tahun 1974-1981. Karirnya sebagai peneliti senior dikembangkan melalui IURS pada tahun 1981-1995. focus penelitiannya berkisar pada usaha transformasi hasil penelitian yang bersifat pluralis-humanis dan menopang posisi kelompok minoritas seperti perempuan dalam usaha menguatkan kedudukan masyarakat sipil. Selain itu, ia juga bertindak sebagai konsultan di United Nation Agencies (UNESCO dan ILO), bank Dunia, Komisi Aga Khan dan terlibat secara aktif dalam gerakan perempuan, di samping ia juga tercatat sebagai anggota Pan Arab Women Solidarity Association.

Pada tahun 1981-1995, ia mengembangkan karirnya sebagai peneliti senior di IURS. Fokus penelitiannya terkait dengan upaya memproduksi penelitian yang berkualitas dan mendesiminasikan ide Islam yang pluralis- 
humanis dan melakukan pemberdayaan perempuan sebagai kelompok subordinatif dalam rangka penguatan masyarakat sipil. ${ }^{8}$ Sebagai seorang feminis, ia memiliki perhatian yang besar terhadap peran-peran perempuan, menganalisa perkembangan historis pemikiran Islam dan manifestasi modernnya. Melalui kajian historisnya terhadap kehidupan Nabi Muhammad saw, ia mengkritik hadishadis misoginis yang mensubordinasi perempuan dan mengoreksinya dengan menafsirkan ayat-ayat al-Qur'an yang justru mengafirmasi kesetaraan manusia.

Karya-karya yang telah ia hasilkan memberikan perhatian besar dalam kaitan dengan pola hubungan laki-laki dan perempuan, serta dominasi dalam sistem masyarakat patriarkhi. Buku-buku tersebut telah dikumpulkan dan dipublikasikan secara murah oleh sebuah jaringan "Femmes Maghreb 2002" sejak tahun 1989-1995. Hal itu dilakukan, sebagai wujud nyata dari dedikasi dan upaya Mernissi untuk menyediakan informasi strategis sekaligus murah bagi masyarakatnya. Beberapa di antaranya adalah: Beyond The Veil Male-Female Dynamics in Modern Muslim Society (1975), The Veil and the Male Elite (1987), Equal Before Allah (bersama Riffat Hasan, 1987), Doing Daily Battle (1989), Women in Islam: In Historical Theological Enquaery (1991), Islam and Democracy: Fear of The Modern World (1992), The Forgotten Queens of Islam (1993), dan Dreams of Trespass Toles of a Harem Gildhood (1994).

\section{Agensi Perempuan}

Secara historis, perempuan telah berpartisipasi di dalam ruang publik dan ikut mewarnai kontestasi politik di dalam sejarah peradaban Islam. Peran publik ini seringkali diabaikan atau dihilangkan oleh mainstream intelektual dan masyarakat Islam, karena adanya kepentingan politis tertentu untuk menjaga kelangsungan status quo atau dominasi laki-laki. Seperti dinyatakan oleh Husein Muhammad, sejarah pemikiran Islam yang sangat panjang ini, banyak menyembunyikan sisi lain pemikiran Islam yang tidak mainstream. Padahal, banyak sekali pemikiran dan opini hukum Islam yang maju, namun tidak populer dan tidak muncul ke

${ }^{8}$ Lihat bagian biografi Fatima Mernissi dalam Fatima Mernissi dan Riffat Hassan, Setara di Hadapan Allah Relasi laki-laki dan perempuan dalam Tradisi Islam pasca Patriarkhi (Yogyakarta: LSPPA, 2000) 
permukaan. Hal ini terjadi karena Islam yang kita warisi ini adalah Islam politik; selalu ada kekuasaan-kekuasaan politik yang memihak pandangan-pandangan tertentu dan melenyapkan pandangan lainnya. Dan baginya, pandanganpandangan utama yang tampil dan didukung penguasa dinasti-dinasti Islam yang berumur panjang, juga jelas-jelas memperlihatkan bentuk wacana yang patriarkhis. ${ }^{9}$

Bias politis dalam sejarah seperti dinyatakan oleh Husen Muhammad, juga dirasakan oleh Fatima Mernissi yang menurutnya telah mengeliminir atau bahkan memelintir peran aktif perempuan dalam ruang publik. Kekuatan-kekuatan tertentu yang menghilangkan peran aktif perempuan dalam sejarah, telah mendiskriminasi perempuan melalui pembentukan citra-citra negatif dan pasif tentang perempuan. ${ }^{10}$ Contoh yang par excellent dalam konteks ini adalah Aisyah. Menurut sebagian orang atau kelompok yang fundamentalis atau bahkan yang mengaku reformis, keterlibatan Aisyah dalam persoalan politis kekuasaan dianggap mewakili citra buruk feminitas yang tidak puas pada status ibu atau istri yang baik. Jamaluddin al-Afghani yang dipandang sebagai pioner reformis Islam, misalnya, menganggap keterlibatan Aisyah dalam persoalan politis justru menimbulkan perpecahan di kalangan umat Islam. Dalam kesimpulannya, ia menegaskan keharusan perempuan untuk diisolir dari urusan politik ${ }^{11}$ karena hanya akan menimbulkan dampak negatif bagi masyarakat.

Sebagai antitesis terhadap pandangan yang minor terhadap perempuan, Mernissi menegaskan bahwa Islam mengafirmasi ide tentang individu sebagai subyek yang memiliki kebebasan dan kesadaran untuk berdaulat yang akan tetap ada selama masih hidup. ${ }^{12}$ Ia juga mengajak umat Islam untuk menelusuri kembali sejarah Islam yang banyak diwarnai oleh partisipasi perempuan bukan sebagai obyek sejarah tapi sebagai subyek sejarah. Berbasis pada berbagai sumber dan

\footnotetext{
${ }^{9}$ http://islamlib.com/id/index.php? page $=$ article \&id $=793$

${ }^{10}$ Fatima Mernissi, "Perempuan dalam sejarah Muslim: Perspektif Tradisional dan Strategi Baru", dalam Fatima Mernissi dan Riffat Hassan, Setara di Hadapan Allah (Yogyakarta: LSSPA, 2000), hal. 176

${ }^{11}$ Ibid, h. 171

${ }^{12}$ Mernissi, The Veil and the Male Elite: A Feminist Interpretations of Women's Rights in Islam, (Inggris: Perseus Books, 1991), hal. 121
} 
karya sejarah yang ditulis oleh para ilmuan, para perempuan memiliki peran yang sangat signifikan dalam formasi kebudayaan dan peradaban Islam, tidak hanya dalam bidang politik saja, tapi juga sosial, budaya, dan lain-lain. ${ }^{13}$ Dalam artikel Salah Ed-Din al-Mounajid, "Apa yang telah ditulis tentang Perempuan", disajikan daftar buku-buku tentang perempuan. Sementara Abul Faraj al-Isbahani, cendekiawan abad kesepuluh, juga menulis Puisi-puisi Budak Perempuan (AlIma' al-Chawa'ir) yang berisi tentang puisi-puisi yang ditulis para budak perempuan yang seringkali dipandang marginal dan subordinatif oleh masyarakat. Karya-karya tersebut menampilkan tokoh-tokoh perempuan terkemuka yang memiliki kapasitas reflektif rasional yang tinggi, sehingga mampu berkontribusi aktif dalam berbagai bidang. Mereka, dipandang oleh Mernissi, sebagai nisa'is (sinonim Arab untuk feminis) yang concern dengan tidak hanya persoalanpersoalan domestik, tapi juga publik. ${ }^{14}$

Dalam bukunya The Veil and the Male Elite, Mernissi mendeskripsikan perempuan yang aktif dan memiliki kapasitas intelektual yang tinggi sehingga berkiprah di ruang publik. Khadijah, istri pertama Nabi misalnya, memiliki inisiatif yang tinggi baik di ruang domestik maupun publik sehingga berhasil dan sukses di kedua ruang tersebut. Dia tidak hanya menjadi penasehat Nabi tapi juga berhasil menjadi wiraswata di dunia perdagangan.

Perempuan lain yang populer adalah Aisyah, istri Nabi yang terkenal kecerdasan dan kiprahnya di panggung politik Arab. Sebagai istri Nabi, ia menjadi salah satu rujukan utama terkait dengan hadis Nabi, sehingga eksistensinya berpengaruh terhadap konstruksi hukum Islam. Kecerdasan dan memorinya yang kuat menjadikannya sebagai referensi penting sekaligus sebagai sumber sahabat untuk melakukan cross-check informasi atau hadis Nabi yang diriwayatkan oleh sahabat lain. Dalam beberapa kesempatan, Aisyah melakukan koreksi terhadap hadis Nabi yang diriwayatkan oleh sahabat lain yang dianggap salah. Contohnya adalah hadis Abu Hurairah yang menyatakan bahwa perempuan yang tidak masuk neraka karena membiarkan kucing betina kehausan dan tidak

\footnotetext{
${ }^{13}$ Ibid., hal. 173

${ }^{14}$ Ibid., hal. 174-175
} 
memberikannya minum. Aisyah mengoreksi hadis tersebut dengan menyatakan bahwa orang yang beriman lebih berharga daripada seekor kucing. ${ }^{15}$

Riwayat Abu Hurairah yang lain adalah terkait dengan persoalan apakah Nabi mensucikan dirinya setelah berhubungan seksual dengan istrinya ketika puasa Ramadhan? Abu Hurairah menyatakan bahwa barang siapa yang pada waktu subuh dalam kondisi junub, maka dia tidak berpuasa. Ketika hadis ini disampaikan kepada Aisyah dan Ummu Salamah, mereka mengatakan bahwa Nabi biasa menghabiskan malam dalam kondisi junub tanpa bersuci dan besok paginya berpuasa. ${ }^{16}$

\section{Gugatan Keadilan Gender Fatimah Mernissi}

Pada awal perjuangan Islam kaum wanita memperoleh kedudukan terhormat, namun hal tersebut berjalan hanya sebentar, karena tahap-tahap selanjutnya kaum wanita makin lama makin ditepikan. Beberapa gugatan keadilan gender yang diperjuangkan oleh Fatimah Mernissi meliputi berbagai hal:

1. Kaum wanita dirasakan kurang (sedikit) yang menjadi ahli kitab suci, padahal dahulu banyak dari kaum wanita yang ahli agama (Salaf al shalihah) dan juga ahli dalam berbagai bidang ilmu dan ahli hadis (muhaddisat), hal inilah yang mendukung terjadinya kekuatan (dominasi) kaum pria dalam meninggikan kaum wanita dan kembali menempati kedudukan selaku pekerja di dalam keluarga.

2. Status kaum pria demikian dominan dalam berbagai bidang kehidupan merupakan dampak yang timbul dari persoalan di atas, sehingga berakibat kaum pria sebagai pemegang kekuasaan untuk menafsirkan teks agama yang berupa Al-Qur'an maupun Al-hadis, sedangkan wanita hanya selaku penerima dari hasil penafsiran tersebut. Pendidikan yang dialami oleh kaum wanita pada akhirnya hanya sekedar sebagai bekal untuk berumah tangga, maka Fatimah Mernissi berpendapat bahwa banyak terjadi penafsiran yang rancu (tidak jelas) terutama ayat-ayat yang berkaitan

\footnotetext{
${ }^{15}$ Ibid., hal. 72

${ }^{16}$ Ibid., hal. 73
} 
dengan kaum wanita, misal: Al-Qur'an Surat Muhammad ayat 15, yang artinya: “Apakah perumpamaan penghuni surga yang dijanjikan kepada orang-orang yang bertaqwa yang di dalamnya ada sungai-sungai dari air yang tiada berubah rasa dan baunya, sungai-sungai dari air susu yang tiada berubah rasanya, sungai-sungai dari khamr (arak) yang lezat rasanya bagi peminumnya dan sungai-sungai dari madu yang disaring; dan mereka memperoleh di dalamnya segala macam buah-buahan dan ampunan dari Tuhan mereka, sama dengan orang yang kekal dalam neraka, dan diberi minuman dengan air yang mendidih sehingga memotongmotong ususnya” .

Al-Qur'an Surat Al-Waqi'ah ayat 27-28, yang artinya: "Dan golongan kanan, alangkah bahagianya golongan kanan itu, Berada di antara pohon bidara yang tidak berduri"

Al-Qur'an Surat Ad-Dukhan ayat 51-54, yang artinya: "Sesungguhnya orang-orang yang bertakwa berada dalam tempat yang aman, yaitu di dalam taman-taman dan mata airmata air; mereka memakai sutera yang halus dan sutera yang tebal, (duduk) berhadaphadapan, demikianlah. Dan Kami berikan mereka bidadari”,

3. Peran serta kaum wanita Islam dirasakan demikian kurang atas pengawasan adanya bahan-bahan sejarah. Bahan sejarah berjalan dari sistem yang rumit, sehingga banyak terjadi manipulasi penafsiran terhadap kitab suci Al Qur'an dan al Hadis. Manipulasi dalam hal ini merupakan ciri khusus para penguasa masyarakat Islam yang terjadi dari abad ke-7 dan seterusnya dibutuhkan legitimasi agama, sehingga kekuatan ekonomi dan politik berupaya untuk memperoleh dukungan teks kitab suci, maka timbullah hadis-hadis palsu untuk keperluan golongan tertentu dan kaum prialah pada akhirnya memiliki kesempatan banyak dalam bidang sosial dan politik. ${ }^{17}$

\section{Kesetaraan laki-laki dan Perempuan dalam Pandangan Fatima Mernissi}

\footnotetext{
${ }^{17}$ A. Sholeh Khudori, Pemikiran Islam Kontemporer, (Yogyakarta: Jendela, 2003), h. 131-133
} 
Islam sangat mengafirmasi kesetaraan laki-laki dan perempuan. ${ }^{18}$ Hal ini didasarkan pada gagasan monoteisme (tauhid) yang tidak hanya bermakna individual personal tapi juga sosial, tidak hanya berdimensi transendental tapi juga profan. Ide mononeisme ini, mengimplikasikan prinsip kemerdekaan manusia yang berarti juga adanya prinsip kesetaraan manusia secara universal. Semua manusia di manapun dan kapanpun, tanpa memandang etnis, bangsa, warna kulit, jenis kelamin, bahasa, kekuasaan, adalah sama dan setara di hadapan Tuhan. Satu pernyataan yang sangat menakjubkan dari Nabi adalah ketika beliau menyampaikan kata-kata Tuhan dalam al-Qur'an tentang gagasan fundamental kesetaraan manusia universal ini.

"Hai manusia, Kami jadikan kamu laki-laki dan perempuan dan Kami jadikan kamu berbangsa-bangsa dan bersuku-suku, supaya kamu saling mengenal. Sesungguhnya yang paling mulia di antaramu adalah yang paling bertakwa”. (Q.S. al-Hujurat: 13)

Ayat ini merupakan satu dari sekian ayat al-Qur'an dan hadis yang berbicara tentang kesetaraan manusia. Kehadiran gagasan ini telah mendekonstruksi kultur masyarakat Arab yang mengukur kualitas dan kemuliaan seseorang berdasarkan etnisitas, kekayaan, kekuasaan dan jenis kelamin, yang kemudian berimplikasi terhadap manifestasi kultural dan praktek sosial, berupa penindasan, subordinasi dan eksploitasi kelompok-kelompok yang tidak mulia, lemah dan marginal. Akibatnya, proses dehumanisasi berjalan secara sistematis dengan adanya legitimasi kultural tersebut.

Ayat lain yang mengusung gagasan kesetaraan manusia adalah surat alAhzab (33) ayat 35:

"Sesungguhnya laki-laki dan perempuan yang muslim, laki-laki dan perempuan yang tetap dalam ketaatannya, laki-laki dan perempuan yang benar, laki-laki dan perempuan yang sabar, laki-laki dan perempuan yang khusyu', laki-laki dan perempuan yang bersedekah, laki-laki dan perempuan yang berpuasa, laki-laki dan perempuan yang memelihara kehormatannya, laki-laki dan perempuan yang banyak menyebut nama (asma') Allah, Allah telah menyediakan untuk mereka ampunan dan pahala yang besar". (QS. al-Ahzab: 35)

\footnotetext{
${ }^{18}$ Fatima Mernissi, Beyond the Veil, Male-Female Dynamics in Modern Muslim Society (Bloomington \& Indianapolis: Indiana University Press, 1987), hal. 19
} 
Ayat ini turun sebagai respon Allah terhadap protes perempuan yang dilakukan oleh Ummu Salamah terhadap Nabi yang menganggap Allah tidak memperlakukan perempuan sama dengan laki-laki. Banyak sekali ayat-ayat alQur'an yang berbicara tentang laki-laki, namun tidak satu pun yang berbicara tentang atau ditujukan kepada perempuan. ${ }^{19}$ Kegelisahan ini, yang juga menjadi kegelisahan para perempuan Arab, disampaikan oleh Ummu Salamah dan direspon oleh ayat di atas yang menegaskan kesetaraan antara laki-laki dan perempuan terkait dengan penghargaan atas prestasinya di dunia baik yang bersifat vertikal maupun horizontal.

Ayat lain yang senada yang juga turun karena protes Ummu Salamah adalah surat 3: 195

"Dan Tuhan mereka mendengar mendengar permohonan mereka dan ia berkata: Sesungguhnya Aku tidak pernah menyia-nyiakan orang yang beramal di antara kamu sekalian, baik laki-laki maupun perempuan”. (QS $3: 195)$.

Ayat ini turun sebagai respon atas protes Ummu Salamah yang mempertanyakan mengapa hanya kaum laki-laki yang hijrah saja yang disebut dalam al-Qur'an, sementara yang perempuan juga melakukan hijrah juga. Ummu Salamah merupakan salah satu perempuan yang ikut hijrah Nabi sebanyak dua kali untuk mendukung perjuangan Islam, yakni dari Mekkah ke Ethiopia dan dari Mekkah ke Medinah. ${ }^{20}$

Ayat ini yang melengkapi ayat-ayat lain tentang kesetaraan manusia, menunjukkan visi dan misi Islam untuk menegakkan dan memberikan kepastian secara mutlak terkait dengan kesetaraan seksual. Momen hijrah sebuah tindakan politis yang melibatkan laki-laki dan perempuan, harus dimaknai sebagai afirmasi dan justifikasi Islam atas partisipasi publik perempuan dalam ranah sosial politik. Perempuan juga memiliki tanggung jawab sosial untuk memperjuangkan

\footnotetext{
${ }^{19}$ Fatima Mernissi, The Veil and the Male Elite, A Feminist Interpretation of Women's Rights in Islam (Inggris: Perseus Books, 1991), hal. 119

${ }^{20}$ Fatima Mernissi, Setara di Hadapan Allah (Yogyakarta: LSPPA, 2000), hal. 228-229
} 
reformasi sosial dan sekaligus mendapatkan balasan atas tindakannya tersebut sama seperti laki-laki. ${ }^{21}$

Nilai kesetaraan sosial ini kemudian diperkuat dengan hadirnya surat anNisa' yang berbicara tentang pemihakan Islam terhadap kaum perempuan yang selama ini dimarginalkan dalam tradisi Arab pra-Islam. Hal ini bisa dilihat dengan hadirnya hukum warisan yang memberikan bagian bagi perempuan. Ketika dalam tradisi pra-Islam, perempuan justru menjadi bagian dari harta suami yang bisa diwariskan kepada anak atau saudaranya, Islam justru memperlakukan perempuan sebagai manusia dan anggota masyarakat yang memiliki kedudukan sama dalam perolehan warisan. ${ }^{22}$

Eksistensi hukum warisan ini tidak hanya bermakna sebagai upaya untuk mengangkat derajat perempuan, tapi juga sekaligus berperan sebagai mekanisme untuk menurunkan superioritas dan hak privilige yang sebelumnya dinikmati dan dimiliki secara mutlak oleh laki-laki. Penguasaan harta yang sebelumnya dimonopoli oleh laki-laki, harus didistribusikan kepada perempuan sebagai perintah agama. Ini tidak saja berdampak secara ekonomis, berupa berkurangnya sumber perolehan harta, tapi juga berdampak secara social, yakni berkurangnya mekanisme penguasaan laki-laki atas perempuan, karena ketika perempuan mendapat warisan maka ia tidak lagi bisa diwariskan. Ide kesetaraan sosial mengalami jalan buntu ketika para prajurit menuntut Nabi untuk membagi harta rampasan perang, yang salah satunya adalah wanita. Meski Nabi lebih suka untuk membebaskan perempuan, namun desakan para prajurit yang mengancam Nabi, membuat Nabi mengalami sikap yang dilematis. Di satu sisi, perang merupakan sarana para prajurit untuk mendapatkan kekayaan, namun di sisi lain Nabi memiliki preferensi untuk membebaskan perempuan dari status tawanan perang. Dalam konteks ini, menurut Mernissi, ruang improvisasi atau manuver Nabi menjadi terbatas, ketika perekonomian masyarakat Arab digerakkan dengan ekonomi perang. ${ }^{23}$

\footnotetext{
${ }^{21}$ Ibid., hal. 229

${ }^{22}$ Mernissi, The Veil, hal. 120

${ }^{23}$ Ibid., hal. 138
} 
Berbasis pada ide kesetaraan tersebut, Islam sangat menentang praktik perbudakan. Meski secara tekstual, tidak ada ayat al-Qur'an yang melarang praktik perbudakan, namun Islam berupaya untuk meredusir atau bahkan mengeliminir praktik dan institusi perbudakan. Hal paling utama dari sikap etis Islam ini adalah menjadikan pembebasan budak sebagai perilaku kedermawanan dan perilaku keimanan seperti dalam surat al-Baqarah ayat 177:

"Bukanlah menghadapkan wajahmu ke arah timur dan barat itu suatu kebajikan, akan tetapi sesungguhnya kebajikan itu ialah beriman kepada Allah, hari kemudian, malaikat-malaikat, kitab-kitab, nabi-nabi, dan emmebrikan harta yang dicintainya kepada kerabatnya, anakanak yatim, orang-orang miskin, musafir, dan orang -orang yang meminta-minta; dan (memerdekakan) hamba sahaya, mendirikan shalat, dan menunaikan zakatdan orang-orang yang menepati janjinya apabila ia berjanji, dan orang-orang yang sabar dalam kesempitan, penderitaan dan dalam peperangan. Mereka itulah orang-orang yang benar (imannya); dan mereka itulah orang-orang yang bertakwa"

Hal kedua adalah afirmasi Islam terhadap kehormatan budak sebagai manusia dengan membuat aturan yang mempengaruhi relasi sosial terutama terkait relasi seksual. Islam melarang menjadikan budak perempuan menjadi pelacur, bahkan menyuruh laki-laki muslim untuk menikahi budak perempuan yang beriman. Rasulullah sendiri mencontohkan praktik membebaskan budak (perang) sebelum menikahinya, seperti ketika menikahi Juwayriyyah binti alHaris. Setelah kekalahan sukunya, ia menjadi bagian dari rampasan perang yang dibagikan kepada salah seorang prajurit, yakni Tsabit bin Qays. Namun. Karena ia berasal dari keluarga aritokrat, ia berusaha melakukan negoisasi untuk dilepaskan dengan syarat membayar sejumlah uang tebusan. Ketika ia datang kepada Nabi dan menjelaskan hal ini, Nabi memberikan solusi dengan membayar uang tebusan untuknya dan kemudian membebaskan dan menikahinya ketika sudah menjadi perempuan merdeka. ${ }^{24}$ Sikap Islam terhadap perbudakan telah mendekonstruksi tradisi dan praktik sosial Arab pra Islam yang menjadikan budak seperti barang atau properti yang bisa diperlakukan sesuai dengan keinginan majikan atau pemiliknya. Bahkan, menurut Mernissi, perbudakan perempuan menjadi sumber

${ }^{24}$ Ibid., hal.149-150 
gratifikasi seksual, sumber pekerja domestik dan reproduksi kekuatan pekerjaan domestik. $^{25}$ Dalam sebuah hadis, Nabi meletakkan dasar etis relasi majikan dan budak/pembantu yang berdasarkan pada kesetaraan dan persaudaraan.

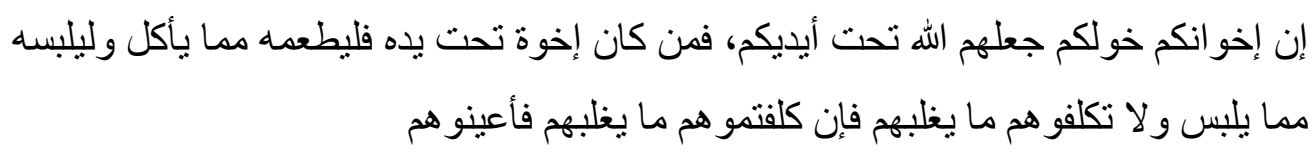

"Sesungguhnya saudaramu adalah pelayanmu yang Allah jadikan mereka berada dibawah perlindunganmu. Maka barang siapa yang saudaranya berada di bawah perlindungannya, maka hendaklah dia memberinya makan seperti yang dia makan, memberikan baju sebagaimana yang dia pakai. Dan janganlah kamu membebani mereka dengan pekerjaan yang tidak bisa diatasi. Dan seandainya kamu membebankan pekerjaan yang berat, maka hendaklah kamu menolongnya".

Redaksi hadis ini sebenarnya إخوانكم خولكم yang berarti sesungguhnya pelayanmu adalah saudaramu, namun kata yang terakhir didahulukan untuk menekankan dimensi persaudaraan dalam relasi majikan-pembantu. Pembantu adalah saudara baik dalam agama maupun kemanusiaan. Karena saudara, maka ia berhak mendapatkan penghormatan dan perlakuan yang manusiawi dari orang yang mempekerjakannya. Dengan etika ini, maka relasi yang terbentuk di antara majikan pembantu bukanlah relasi yang eksploitatif dan subordinatif yang menimbulkan sikap merendahkan dan menindas, tapi relasi yang equal (setara). Relasi ini bersifat equal karena hubungan antara keduanya bersifat komplementer (saling melengkapi).

Meski dalam realitasnya praktik pembebasan budak hal yang relatif biasa, tapi memperlakukannya setara dengan yang merdeka merupakan transformasi sosial yang radikal, sehingga tidak mudah diterima oleh para sahabat. Kasus penunjukan Usama anak Zayd yang dibebaskan Nabi sebagai komando pasukan militer, misalnya, menimbulkan oposisi yang kuat dari para prajurit. Namun demikian, Nabi tetap menunjuk Usama sebagai pemimpin. ${ }^{26}$ Konsistensi ini menunjukkan semangat Islam akan kesetaraan manusia harus ditegakkan karena selain sesuai dengan konsep tauhid, juga sesuai dengan nilai-nilai kemanusiaan

${ }^{25}$ Ibid., hal. 132
${ }^{26}$ Ibid., hal. 150 
universal yang akan berdampak pada konstruksi struktur sosial yang setara dan humanis.

Mernissi menjelaskan bahwa penolakan yang sengit bahkan oleh sahabat, menunjukkan bahwa kesetaraan manusia yang merdeka dengan budak akan berdampak secara serius dalam aspek ekonomi. Praktik ini akan mengancam kepentingan ekonomi tidak hanya kelompok penguasa, tapi juga para prajurit karena budak merupakan bagian dari kekayaan atau properti. Membebaskan budak berarti kehilangan satu bentuk kekayaan. Oleh karena itu, tradisi pra Islam sangat menjaga institusi perbudakan dan menutup seminimal mungkin ruang untuk membebaskan budak."The institution is kept going by only two lawful means: birth in slavery or capture in war". ${ }^{27}$ Kedua cara yang legal ini sangat efektif untuk menjamin kelangsungan dan bahkan kontinuitas praktik perbudakan. Hal ini tentu saja akan menguntungkan dan bermanfaat baik secara ekonomis, sosial maupun politik.

Penghormatan terhadap kesetaraan manusia ini juga berpengaruh dalam perlakuan Nabi terhadap perempuan. Tradisi Arab pra Islam memperbolehkan suami memperlakukan istrinya sesuai dengan kemauannya, apalagi kalau istri melakukan pelanggaran atau menolak permintaan suami. Nabi justru mencontohkan hal yang sebaliknya, yakni menghormati mereka dan tidak pernah melukai istrinya. Hal ini, misalnya dicontohkan dengan sikap Rasulullah ketika menerima pengaduan seorang perempuan yang dipukul oleh suaminya. Ketika Nabi mau menyampaikan keputusannya, turun ayat nusyuz dalam surat an-Nisa ayat 34 yang berbunyi:

"Kaum laki-laki itu adalah pemimpin bagi kaum wanita, oleh karena Allah telah melebihkan sebagian mereka (laki-laki) atas sebagian yang lain (wanita), dan oleh karena mereka (laki-laki) telah menafkahkan sebagian dari harta mereka. Sebab itu maka wanita yang saleh, ialah yang taat kepada Allah lagi memelihara diri ketika suaminya tidak ada. Oleh karena Allah telah memelihara mereka. Wanita-wanita yang kamu khawatirkan nusyuznya, maka nasehatilah mereka dan pisahkanlah mereka di tempat tidur mereka, dan pukullah mereka. Kemudian jika mereka mentaatimu, maka janganlah kamu mencari-cari jalan untuk menyusahkannya. Sesungguhnya Allah Maha Tinggi lagi Maha Besar”.

${ }^{27}$ Ibid 
Sebelum menyampaikan keputusan Tuhan yang membolehkan suami memukul istrinya yang terdapat di ayat tersebut, Rasulullah mengatakan bahwa "I wanted one thing, and God wanted another". ${ }^{28}$ Ini menunjukkan bahwa meski Allah membolehkan suami memukul istrinya, tapi Nabi tidak berkenan dengan perlakuan tersebut. Hal ini dibuktikan bahwa ketika Nabi mengalami masalah domestik (penentangan dari istrinya), ia tidak memukul mereka tapi hanya meninggalkan rumah dan menyepi di ruangan yang berdampingan dengan Masjid selama sebulan. $^{29}$

\section{Kritik Atas Interpretasi Fatima Mernissi}

Dalam pemikiran Fatima Mernissi sebagai salah satu feminis muslim masih terjebak dalam krisis penafsiran dan konter penafsiran. Krisis ini muncul karena cara atau strategi yang digunakan oleh penentang dan pendukung kesetaraan gender dalam membangun dan melegitimasi masing-masing pandangannya pada dasarnya sama, yakni dengan menjelaskan bagian-bagian tertentu dari teks alQur'an atau hadis yang sesuai dan mendukung kepentingan dan pandangan mereka. Bagian-bagian dari teks tersebut kemudian dianggap sebagai asl yang paling benar dan orisinal, yang pada gilirannya cenderung diinterpretasikan secara sepihak sesuai dengan kepentingan dan posisi ideologis mereka dan sekaligus mengeliminasi makna yang tidak diinginkan karena bertentangan dengan kepentingan ideologisnya. Model pembacaan eklektik ini disebabkan karena ketidakmampuan untuk menantang paradigma pembacaan teks yang ada, yang tidak mempertimbangkan konteks historis, aspek dialogis dan komunikatif teks dengan konteksnya, serta dimensi deskriptifnya.

Disini pertama Fatima hanya mereview ayat-ayat yang dikutip oleh lakilaki untuk menegaskan ketidaksejajaran (inequality) antara laki-laki dan perempuan; kedua, mengutip ayat yang secara jelas menyatakan kesejajaran (equality); dan ketiga, mendekontruksi ayat-ayat yang concern pada ketidaksamaan laki-laki dan perempuan. Mekanisme pendekatan seperti ini,

\footnotetext{
${ }^{28}$ Ibid., hal. 155

${ }^{29}$ Ibid., hal. 157
} 
seperti juga dilakukan oleh para reformis, tidak baru dan orisinal, karena menurutnya hermeneutika feminis menghadapi persoalan bahwa "as long as the Quran is dealt with only as a text - implying a concept of author (i.e. God as divine author) - one is forced to find a focal point of gravity to which all variations should be linked". ${ }^{30}$ Hal ini secara otomatis akan menimbulkan persepsi bahwa penafsiran al-Qur'an akan sangat tergantung pada ideologi penafsir. Oleh karenanya, berbagai ideologi yang berbeda akan memperoleh justifikasi pandangannya dalam al-Qur'an.

Untuk mencari legitimasi kesetaraan seksual dalam Islam, Mernissi cenderung hanya menafsirkan ayat-ayat yang mendukung ide tentang kesetaraan manusia. Sementara ayat-ayat lain yang tidak mendukung ide tersebut ditafsirkan secara mendalam dengan menelusuri asbab an-nuzul baik mikro (sebab khusus yang melatarbelakangi turunnya ayat) maupun makro (kondisi obyektif sosial budaya masyarakat Arab). Selain itu untuk mengkounter ayat-ayat yang subordinatif terhadap perempuan, ia hanya mencari hadis atau tradisi Nabi yang memiliki makna yang berbeda dengan ayat itu atau memiliki spirit yang berbeda dengan ayat tersebut, seperti dalam kasus nusyuz.

Mekanisme ini menunjukkan adanya politisasi teks religius untuk melegitimasi kepentingan tertentu dengan menafsirkan ayat atau teks secara parsial dan tidak komprehensif. Perlakuan seperti ini justru akan memudahkan pihak lain yang pro subordinasi perempuan untuk mengkounter pandangan Mernissi dengan mengambil teks-teks agama sesuai dengan kepentingannya juga. Hal ini menurut Nasr Hamid Abu Zayd dianggap sebagai bentuk ideologisasi penafsiran, karena menafsirkan teks tidak secara obyektif menggunakan mekanisme teks itu sendiri baik secara internal maupun eksternal, tapi justru memaksakan kepentingan atau pandangan tertentu untuk dicari pembenarannnya dari teks.

Dalam konteks ini, Abu Zayd menawarkan penafsiran bahwa ayat-ayat yang berbicara kesetaraan antara laki-laki dan perempuan dalam semua aspek

\footnotetext{
${ }^{30}$ Nasr Hamid Abu Zayd, Reformation of Islamic Thought a Critical Historical Analysis, (Amsterdam: Amsterdam University Press, 2006), h. 91
} 
kehidupan baik yang bersifat profan maupun religius, menunjukkan apa yang ingin diperjuangkan oleh teks. Sementara teks-teks agama yang memberikan pembedaan antara laki-laki dan perempuan dengan menempatkan perempuan di posisi yang lebih rendah, harus dipahami secara kontekstual dengan melihat background cultural masyarakat Arab saat itu. Dengan menggunakan tesis Abu Zayd bahwa sebuah teks merupakan produk historis dan kultural di mana teks tersebut hadir, maka teks merupakan representasi pemikiran atau kebudayaan dari masyarakat yang melahirkan teks tersebut. Dengan demikian, teks tidak hadir dalam ruang hampa sejarah dan bersifat otonom. Sebuah teks dapat bermakna secara eksistensial dalam sebuah masyarakat jika ia memiliki basis kultural komunitas masyarakat yang melingkupinya. Dalam konteks ini, budaya berperan sebagai produsen teks, sehingga realitas-realitas yang tergambar di dalam teks, sebagian mencerminkan realitas sosial budaya dari masyarakat yang membentuknya. Sebaliknya, teks juga memiliki peran sebagai produsen budaya. Artinya teks memiliki efektivitas untuk mempengaruhi dan mengubah budaya yang kemudian direkonstruksi dalam bentuknya yang baru. Hubungan antara teks dan budaya dalam kedua sisinya tersebut di atas bersifat dialektis dan kompleks, tidak bersifat linear dan pasif. ${ }^{31}$

Dengan teori ini, maka teks-teks agama yang mensubordinasi perempuan merupakan representasi kedudukan perempuan pada masyarakat Arab Jahiliyyah. Hal ini berarti, konsepsi itu bersifat lokal dan temporer, karena kondisi perempuan saat ini jauh berbeda dengan kondisi perempuan yang ditampilkan dalam teks-teks tersebut. Oleh karenanya, Quraish Shihab menyatakan bahwa para ulama dahulu akan memberikan penafisran yang berbeda, ketika mereka hidup pada situasi sekarang dimana perempuan dapat mengakses perkembangan ilmu pengetahuan dan teknologi sehingga dapat meningkatkan kualitas keilmuannya.

\footnotetext{
${ }^{31}$ Nasr Hamid Abu Zayd, Mafhum an-Nashsh, (Bairut: Al-Markaz al-Thaqafi Al-Arabi, 1998), hal. 24-25
} 


\section{PENUTUP}

Dalam upaya rekonstruksinya, Fatima Mernissi menggali nilai-nilai dan ajaran dalam al-Qur'an yang menegaskan dan mengafirmasi kesetaraan laki-laki dan perempuan. Dengan mengutip beberapa ayat al-Qur'an, Mernissi menegaskan bahwa visi dan misi Islam menegakkan dan memberikan kepastian secara mutlak terkait dengan kesetaraan seksual. Momen hijrah sebuah tindakan politis yang melibatkan laki-laki dan perempuan, harus dimaknai sebagai afirmasi dan justifikasi Islam atas partisipasi publik perempuan dalam ranah sosial politik. Perempuan juga memiliki tanggung jawab sosial untuk memperjuangkan reformasi sosial dan sekaligus mendapatkan balasan atas tindakannya tersebut sama seperti laki-laki. Selain itu, Islam mengafirmasi kehormatan budak sebagai manusia dengan membuat aturan yang mempengaruhi relasi sosial terutama terkait relasi seksual. Islam melarang menjadikan budak perempuan menjadi pelacur, bahkan menyuruh laki-laki muslim untuk menikahi budak perempuan yang beriman.

Dari diskursus di atas, menjadi jelas bagi kita bahwa optik kultural akan selalu muncul dalam setiap perdebatan tentang feminisme, begitu pula kecenderungan interpretasi tertentu (baca: pra teks) ikut juga terlibat (enveloped) dan bahkan ikut bermain di dalamnya. Oleh sebab itu, munculnya pandanganpandangan yang berbeda bahkan agak "bias" sudah dianggap lumrah. Seseorang dalam membicarakan feminisme tidak akan dapat memposisikan diri dengan benar-benar obyektif tanpa pretensi, melainkan hanya dapat menjaga jarak terhadap prasangka (Prejudices) atau "bias" yang tanpa disadari dapat saja muncul termasuk pandangan Fatima Mernissi mengenai kesetaraan laki-laki dan perempuan. 
222 | Lub Liyna Nabilata / Hermeneutika Feminis...

\section{DAFTAR RUJUKAN}

Hamid, Nasr, Abu Zayd, Reformation of Islamic Thought a Critical Historical Analysis, (Amsterdam: Amsterdam University Press, 2006)

http://islamlib.com/id/index.php?page $=$ article \&id $=793$

Mernissi, Fatima, Setara di Hadapan Allah Relasi laki-laki dan perempuan dalam Tradisi Islam pasca Patriarkhi (Yogyakarta: LSPPA, 2000) , Beyond the Veil, Male-Female Dynamics in Modern Muslim Society (Bloomington \& Indianapolis: Indiana University Press, 1987)

Women's Rights in Islam (Inggris: Perseus Books, 1991) , The Veil and the Male Elite, A Feminist Interpretation of , Women and Islam: An Historical and Theological Inquiry, alih bahasa oleh Yaziar, (Bandung: Pustaka, 1991)

Mulia, Musdah, Indahnya Menyuarakan Kesetaraan dan Keadilan Gender, (Yogyakarta: Naufan, 2014)

Ilahi, (Bandung: Marja, 2011)

, Muslimah Sejati Menempuh Jalan Islami, Meraih Ridho

Nasr Hamid Abu Zayd, Mafhum an-Nashsh, (Bairut: Al-Markaz alThaqafi Al-Arabi, 1998)

Sholeh A, Khudori, Pemikiran Islam Kontemporer, (Yogyakarta: Jendela,

Umar, Nasaruddin, Argumen Kesetaraan Gender: Perspektif Alquran, (Jakarta: Paramadina, 1999) 